\title{
Defining Bullying among Students from Criminal Law Perspective: Comparison between Malaysia and the Philippines
}

\author{
Ramalinggam Rajamanickam ${ }^{1, *}$, Farah Shuhada Ramli ${ }^{2}$, Mohd Safri Mohammed Na'aim³, \\ Muhamad Sayuti Hassan ${ }^{4}$, Hasnizam Hashim ${ }^{5}$ \\ ${ }^{1}$ Faculty of Law, Universiti Kebangsaan Malaysia (UKM), Malaysia \\ ${ }^{2}$ High Court of Kuala Lumpur, Malaysia \\ ${ }^{3}$ Centre of Foundation Studies, Universiti Teknologi MARA, Cawangan Selangor, Kampus Dengkil, Malaysia \\ ${ }^{4}$ Faculty of Human Science, Universiti Pendidikan Sultan Idris (UPSI), Malaysia \\ ${ }^{5}$ Faculty of Syariah \& Law, Universiti Sains Islam Malaysia (USIM), Malaysia
}

Copyright $\bigcirc 2019$ by authors, all rights reserved. Authors agree that this article remains permanently open access under the terms of the Creative Commons Attribution License 4.0 International License

\begin{abstract}
School bullying is not new, but it has been a long and constant problem. Bullying issues are often reported in the mass media and have garnered attention not only in Malaysia but also abroad. Today, bullying can no longer considered as a trivial social problem that can be taken lightly. Failure to address this issue will have bad consequences for students in particular. Various ways have been introduced to tackle this issue and one of them is through the enforcement of law. This study will focus on the bullying within the legal framework in Malaysia, especially in the context of its definition. Studies showed that while in Malaysia, there are alarming statistics about bullying, but little attention has been paid to the absence of any specific law dealing with bullying in Malaysia. To date, no statutory definition of bullying has been provided. This paper thus provides an overview of Malaysia's legal framework of bullying compared with the Philippines law on bullying. Despite a number of definitions of bullying provided by the scholars, the paper concludes that to date, there are no specific law on bullying and its statutory definition in Malaysia. Such absence may not fully safeguard the interests of bullying victims comprehensively. The findings would give more clarity to the theoretical framework of bullying in Malaysia thus showing the commitment of the government towards preventing the rampancy of this issue through legal enforcement.
\end{abstract}

Keywords Bullying, School Students, Enforcement of Law, Criminal Justice System, Malaysia

\section{Introduction}

Bullying may occur wherever groups of individuals meet. Being together for a period of time enabling bullies to observe others around them and learn about their pattern of behaviors. This gives them an opportunity to identify those who are vulnerable and easy to be bullied. Smith [1] found that bullying is not only limited to school, but also may take place anywhere such as at workplace. He further explained that apart from bullying in schools, there are many literatures about bullying at workplace and bullying of adults in prison [2]. For the purpose of this article, it will focus on school bullying. This is because school bullying has been widely studied in recent decades following systematic studies pioneered by Olweus in 1970s [3]. School bullying is not new, but it has been a long and constant problem. Bullying may be carried out by a person or a group of persons with power to someone who is seen weak, alone and unable to defend themselves [4]. School bullying happens irrespective of gender [5]. Sivaraman, Nye, \& Bowes [6] linked bullying with anti-social and violent behaviour. Türkmen, Dokgöz, Akgöz, Eren, Vural \& Polat [7] claimed that bullying issues are often reported in the mass media, and has garnered attention worldwide including Malaysia. Audrey Vijaindren [8] reported that the statistics from the Ministry of Education Malaysia revealed that there were more than 14,000 cases of bullying in schools between 2012 and 2015, and most of them involve physical bullying. This figure indicates that bullying is alarming and prevalent. This shows that there are students who are inclined to involve in bullying activities. It would be worrying to realize that some students in Malaysia are prone to bullying activities, because they are hoped to be the future leaders. It would therefore be petrifying to place the stewardship of this country in their hands if no action or measures were to be taken. 
There are a number of factors that lead to school bullying. Research found that among the reasons include lack of interest in school, family factors and the influence of bad peers [9]. Bullying is a terrifying experience especially for children who cannot really protect themselves and feel powerless to prevent it. Wolke \& Lereya [10] identified that the bullying of victims has affected victims' health, in particular anxiety disorders, depression, headaches, suicidality and self-harm. Thus, bullying is a serious matter and if not handled properly, it could lead to health problems.

School bullying research has become a growing concern around the world in the last decades. There has been an increasing amount of literature, which proposes methods to address this issue. Olweus [11], Rigby [12] and Smith [13] proposed school-based interventions to tackle the issue of bullying. Rigby [12] identified several intervention programmes to address the issue of bullying in school, namely empowering the victim, mediation and the support group method. However, up to now, the need to have a specific law to address the bullying issue in Malaysia has not been given much attention yet.

In light of recent Zulfarhan's case, the spotlight has been casted on the issue of bullying and the importance of the need for legislation relating to bullying. In this case, Zulfarhan Osman Zulkarnain was a Universiti Pertahanan Nasional Malaysia cadet officer who died from physical injuries and was believed to have been inflicted by his university mates. He was beaten, kicked and inflicted with a hot steam iron by 19 students of the University for refusing to confess that he had stolen a laptop [14]. Thus, this paper provides an overview of the bully definition given by scholars with reference to several sections, which relate to the current provision in the Penal Code that have been used in handling bully cases.

The findings would give more clarity to the theoretical framework of bullying in Malaysia thus complying with the responsibility to protect children from all forms of abuse including bullying as spelt out in the Convention of the Rights of the Child (CRC). Malaysia has signed and ratified the $\mathrm{CRC}$ in 1995. In general, $\mathrm{CRC}$ is a human rights treaty, which set out civil, political, economic, social, health and cultural rights of children. The CRC was officially accepted by the 44th United Nations (UN) on 20 November 1989 on a consensus basis. The Convention contains 54 Articles, which outline the rights to be given to children. Among the rights and protection proposed is the right to be protected from all forms of physical, mental and sexual abuse. A reading of Article 19 of the CRC clearly states that the State Parties (including Malaysia) should take all measures including legislative approach to protect the child from all forms of physical or mental violence, injury or abuse. This is explicitly set out in Article 19 of the CRC, which states as follows:

Parties shall take all appropriate legislative, administrative, social and educational measures to protect the child from all forms of physical or mental violence, injury or abuse, neglect or negligent treatment, maltreatment or exploitation, including sexual abuse, while in the care of parent(s), legal guardian(s) or any other person, who has the care of the child.

In Malaysia, when bullying is reported to the police, it will be investigated in accordance with criminal law. Upon completion of the investigation, the bullying may be classified as a specific offence provided by the criminal law depending on the effects of bullying to the victims. However, if the outcome of the investigation shows that it does not fall within the purview of provisions of criminal law, bullying will not be classified as a criminal offence. In this context, it is clear that Malaysian criminal law does not cater all types of bullying acts. It covers only acts of bullying which harm the victim physically. The question may arise as to whether non-physical bullying, such as psychological and emotional harms, which are caused by the bullying acts is considered as a criminal offence. This issue is vital to be resolved because of two main reasons. Firstly, non-physical bullying can negatively impact on the current and future academic performance of the victims [15]. In addition to that, it also can greatly impact on the intrapersonal and interpersonal skills of the victims. Secondly, among the functions of criminal law are for prevention and rehabilitation. The absence of provision on definition of bullying and its related offences will frustrate the function of criminal law as a preventive mechanism. Furthermore, when the law is not in place, then the bullies cannot be charged and rehabilitation program for bullies cannot be carried out.

Thus, this article intends to address how criminal law in Malaysia defines bully through its existing provisions. This article will also take into consideration the child law in Malaysia, as the school students are defined as a child under the Malaysian law.

\section{Materials and Methods}

This research is qualitative in nature with a pure legal approach. This research adopted a content analysis method consisting of a detailed analysis of the Penal Code and the Child Act 2001. In addition to that, this research also analysed the journals and academic research in this area to discuss on the legal framework of bullying in Malaysia. Moreover, this research compares the legal framework on bullying among school students in Malaysia with Philippines.

\section{Definition of Bullying and Cyberbullying}

The main question at this juncture is what the definition of bullying is. Defining bullying is essential in order to understand its scope and thus strive to provide adequate protections for the victims of bullying. Incomprehensive 
definition will lead in some bullying acts or words not being counted as bullying, leaving the victim's interest unprotected. It has been argued that defining bullying may be a difficult task [16].

\subsection{Bullying}

Olweus defined bullying as "when someone repeatedly and on purpose says or does mean and hurtful things to another person who has a hard time defending himself or herself" [17]. The definition signifies several elements to constitute bullying which are: (i) repetition; (ii) intention to harm either through words or actions; and (iii) the inability to defend himself indicates a bully is in power over the victim. The second criterion shows that bullying is a subset of aggression, which is perpetrated through acts and words. The third criterion implies that there is an imbalance of power between the bully and the victim [18]. The meaning of imbalance of power does not confine itself to the distinction between the physical power of bully and victim that is widely interpreted to include the social status and group size [19].

Nevertheless, this definition do not have problem. Some researchers do not agree with the first criterion, which is repetition. Volk believed repetition is not compulsory elements. The argument is that a single terrible attack (high intensity) is enough to permanently harmfully affect a victim's psychology and behavior. However, if the act of aggression is less harmful (low intensity), but repeated over a period of time, it may equally cause harmful effect on the victim [20]. So, harm committed against a victim may rely on the intensity of the action through the resilience of that person. This shows that repetition is not a necessary criterion for bullying [21].

Olweus's definition of bullying had been referred to by the local scholars to define bullying [22]. However, referring to the definition given by Azizi $\mathrm{Hj}$ Yahaya and Abdul Latif Ahmad [23], criterion of repetition is not part of the definition of bullying.

The Ministry of Education [24] through its circular describes bully as "orang yang menggunakan kekuatan atau kekuasaannya untuk menakutkan atau menyakitkan orang yang lebih lemah." This definition is more consistent with Volk's definition of bullying which excludes repetition as an essential requirement. This line of definition is more practical in the context of schools in Malaysia because the preventive measures can be implemented immediately at earlier stage to stop its rampancy rather than waiting at the latter stage which may result in undesired outcome such as grievous injuries or even death.

\subsection{Cyberbullying}

In addition to bullying, cyberbullying is also an increasing issue nowadays among students. Social media like Facebook, Instagram and Twitter have changed the way of individuals' interaction today. Today's communication is not confined to physical eye-to-eye meeting, but can occur everywhere as long as the person has smartphones or computers. Rather than using the technologies for good reasons, there are students who utilize them as a means to spread rumors, embarrassing stories and obscene images to humiliate their friends. The question is whether cyberbullying can also be regarded as bullying. Smith [25] argued that by extending the definition from traditional bullying, cyberbullying could be defined as "an aggressive act or behaviour that is carried out using electronic means by a group or an individual repeatedly and over time against a victim who cannot easily defend him or herself". This definition however may cause difficulty in the application particularly with the requirement of repetition. This is because A may be firstly responsible for spreading obscene picture of $\mathrm{B}$. But later the same picture will be shared repeatedly by other individuals until it widely spread to the public at large causing humiliation to $B$. If repetition were accepted as the requirement of cyberbullying, then $\mathrm{A}$ may not be responsible for bullying which may be unfair to $\mathrm{B}$ because the same picture has been share repeatedly by different persons. The criterion of imbalance of power may make it difficult to prove, because act of cyberbullying does not take place at physical place but happens through the realm of cyber. Vandebosch and Van Cleemput [26] argued that a higher understanding of ICTs can contribute to an imbalance of power and discovered that students with better internet abilities are more likely to have experience with different Internet and mobile phone activities.

In conclusion, cyberbullying may differ from the traditional meaning of bullying because cyberbullying has its own unique characteristics. The relevancy of traditional criteria of bullying, namely repetition and imbalance of power have to be carefully considered to ensure they do not impede the enforcement of law over cyberbullying.

\section{Bullying under the Malaysian Penal Code}

Malaysian education system is governed by the Education Act 1996 (EA 1996). According to section 15 of the EA 1996, the national education in Malaysia can be categorized into five levels, namely pre-school education, primary education, secondary education, post-secondary education and higher education. The current article focuses on the primary and secondary schools' students which ranging from 7 years old to 17 years old due to two main reasons. Firstly, they fall within the definition of a child under the Child Act 2001. Secondly, they are vulnerable to many bullying acts either as victims or bullies.

In the Malaysian context, under the Penal Code, the word 'bullying' has not been mentioned in any sections. However, this does not mean that the bullies will escape any legal implications of their actions. This is because 
based on the above definitions, bullying consists of a number of elements that may fall under offending provisions of the Penal Code [27].

If the bullies cause hurt to victim, then such act will be an offence under section 323 of the Penal Code. If the hurt caused is grievous, then offence under section 325 of the Penal Code has been committed. Further, if both offences are committed using dangerous or deadly weapons, then offences under section 324 and 326 of the Penal Code have been committed respectively. In the worst case, if bullying results in the death of the victim, then offences under sections 302 or 304 of the Penal Code has been committed depending on the mens rea of the bullies.

In addition, if bullies commit assaults or uses criminal force to victim, then offence under section 352 of the Penal Code has been committed. The meaning of the words 'assault' and 'criminal force' can be seen in sections 351 and 350 of the Penal Code respectively. For the former, it means:

Whoever makes any gesture or any preparation, intending or knowing it to be likely that such gesture or preparation will cause any person present to apprehend that he who makes that gesture or preparation is about to use criminal force to that person.

Meanwhile, for the latter it can be defined as:

Whoever intentionally uses force to any person, without that person's consent, in order to cause the committing of any offence, or intending by the use of such force illegally to cause, or knowing it to be likely that by the use of such force he will illegally cause injury, fear, or annoyance to the person to whom the force is used.

Some illustrations under section 350 of criminal forces demonstrate some acts that often be described as "bully" which are illustrations (d), (e) and (f) of section 350 of the Penal Code as follow:

d. A intentionally pushes against $\mathrm{Z}$ in the street. Here $\mathrm{A}$ has by his own bodily power moved his own person so as to bring it into contact with $\mathrm{Z}$. He has therefore intentionally used force to $Z$, and if he has done so without Z's consent, intending or knowing it to be likely that he may thereby injure, frighten or annoy $Z$, he has used criminal force to $\mathrm{Z}$.

e. A throws a stone, intending or knowing it to be likely that the stone will be thus brought into contact with $Z$, or with Z's clothes, or with something carried by Z, or that it will strike water and dash up the water against Z's clothes, or something carried by Z. Here if the throwing of the stone produces the effect of causing any substance to come into contact with Z, or Z's clothes, A has used force to $Z$; and if he did so without $Z$ 's consent, intending thereby to injure, frighten or annoy $Z$, he has used criminal force to $Z$.

f. A intentionally pulls up a woman's veil. Here A intentionally uses force to her; and if he does so without her consent, intending or knowing it to be likely that he may thereby injure, frighten or annoy her, he has used criminal force to her.

Furthermore, bullying also may fall under offence of criminal intimidation under section 506 of the Penal Code. Criminal intimidation is defined under section 503 of the Penal Code as:

Whoever threatens another with any injury to his person, reputation or property, or to the person or reputation of any one in whom that person is interested, with intent to cause alarm to that person, or to cause that person to do any act which he is not legally bound to do, or to omit to do any act which that person is legally entitled to do, as the means of avoiding the execution of such threat, commits criminal intimidation.

Apart from the above provisions, bullying may also fall under section 148 of the Penal Code. The section basically outlaws committing riot which is punishable with imprisonment for a term which may extend to two years or with fine or with both.

Looking at the aforementioned provisions, the offences are committed only when the victims are physically harmed namely under sections 302, 304, 323, 324, 325, 326 and 350 of the Penal Code. In addition, an offence can also be committed without physical contact as mentioned in sections 351 and 506 of the Penal Code. Both sections 351 and 506 of the Penal Code do not require the element of touching. For the former, it is sufficient to prove that the bullies have made gestures with the intention to carry out criminal force. For the latter, what needs to be proven is the threat made by the bullies to the victim, among others, to cause death or grievous hurt or to cause an offence punishable with death or imprisonment.

It is worth noting that the above offending provisions are general and may apply to bullying situations. The act of bullying may fall within one of the above provisions or a combination of several provisions. While the provisions above may apply in situations of bullying, but when bullies are charged in court under these sections, the public perceives that bullies are not charged for bullying, giving the public the impression that the government is not sufficiently serious to deal with this issue. It is important to note that some of the bullying acts may not fall under the offending sections such as acts committed or words uttered for the purposes of making fun of the victims. The acts may not contain any element of making gestures to execute criminal force or to threaten the life of the victim himself. At first glance, they may be viewed as trivial but if repeated for long time and satisfy the three criteria of bullying would result in harmful effect on to the victims. Therefore, in order to provide extensive protection for bullying victims, a specific law on bullying is needed.

It is important to note that in the context of school bullying in Malaysia, Form 5 students and below are usually below eighteen years old and do not reach yet the age of majority as spelt out in section 2 of the Age of 
Majority Act 1971. Thus, students of primary and secondary schools in Malaysia are considered as a child as defined by section 2 of the Child Act 2001. This definition is consistent with the interpretation set out in Article 1 of the CRC. In relation to criminal proceedings, 'child' is a person who has attained the age of criminal responsibility as prescribed in section 82 of the Penal Code. The section basically set the minimum age of criminal responsibility at the age of 10 years. The section says "Nothing is an offence which is done by a child under ten years of age." This demonstrates that Malaysian criminal law offers complete protection for children under the age of 10 who commit offences. They are given full exemption from their criminal responsibility since they are considered doli incapax, a Latin term, which is literally translated as incapable of doing wrong [28]. Thus, students, whose age fall within the range, if found guilty for offence committed, will be dealt by the Child Act 2001, namely under section 91 and not under the Penal Code itself. The section states as follows:

If a Court for Children is satisfied that an offence has been proved the Court shall, in addition to any other powers exercisable by virtue of this Act, have power to-

(a) admonish and discharge the child;

(b) discharge the child upon his executing a bond to be of good behaviour and to comply with such conditions as may be imposed by the Court;

(c) order the child to be placed in the care of a relative or other fit and proper person-

i. for such period to be specified by the Court; and

ii. with such conditions as may be imposed by the Court;

(d) order the child to pay a fine, compensation or costs;

(e) make a community service order;

(f) make a probation order under section 98 ;

(g) order the child to be sent to an approved school or a Henry Gurney School;

(h) [Del. Act A1511]

(i) impose on the child, if he is aged fourteen years and above and the offence is punishable with imprisonment and subject to subsection 96(2), any term of imprisonment which could be awarded by a Session Court.

In light of section 91 of the Child Act 2001, the above orders can be imposed by the Court only if the offence has been proved. Impliedly, the above court orders cannot be imposed against the bullies if bullying is not governed by any law in Malaysia. Therefore, definition of bullying within the criminal law context is pertinent for the application of the Child Act 2001. It must be noted that in Malaysia, although offences committed by bullies (children) are investigated and charged under the criminal law, but the punishment will be in accordance with the Child Act 2001 in the form of court orders. The said section empowers the court to impose various forms of orders on a child such as release on bond of good behavior, sending to approved schools and doing community service, taking into account the best interest of the child (bullies and victims).

\section{Legal Position of Bullying in the Philippines}

For the purpose of this paper, reference will be made to the Philippines law of bullying. The reason is that the Philippines had enacted its own law on bullying that can be seen in its Anti-Bullying Act of 2013 (Philippines, Republic Act No. 10627).

As far as the bullying is concerned, section 2 of Anti-Bullying Act of 2013 defines the term as:

Any severe or repeated use by one or more students of a written, verbal or electronic expression, or a physical act or gesture, or any combination thereof, directed at another student that has the effect of actually causing or placing the latter in reasonable fear of physical or emotional harm or damage to his property; creating a hostile environment at school for the other student; infringing on the rights of the other student at school; or materially and substantially disrupting the education process or the orderly operation of a school.

For ease reference, the section further illustrates circumstances that may fall within the ambit of the definition. The illustrations are not exhaustive but include the following:

a. any unwanted physical contact between the bully and the victim like punching, pushing, shoving, kicking, slapping, tickling, headlocks, inflicting school pranks, teasing, fighting and the use of available objects as weapons;

b. Any act that causes damage to a victim's psyche and/or emotional well-being;

c. Any slanderous statement or accusation that causes the victim undue emotional distress like directing foul language or profanity at the target, name-calling, tormenting and commenting negatively on victim's looks, clothes and body; and

d. Cyber-bullying or any bullying done through the use of technology or any electronic means.

This section shows that bullying may be committed if it falls under paragraphs (a) to (d). Firstly, the bullying may take place if there is any undesired physical contact between bully and the victim. The purpose of contact is not necessarily to harm the victim. It may also include school pranks and teasing as long as the victims disapprove the acts. Secondly, the effect of the bullying act is not only confined to physical but also emotional damage. Thirdly, paragraph (c) stresses the possibility of committing bullying through words namely slander and accusation. Notably, bullying includes cyberbullying and therefore 
prohibits any acts of bullying through electronic means. A thorough reading of this section indicates that the law does not include the criterion of power imbalance as the requirements to prove bullying. Meanwhile, the element of repetition is not made mandatory. The words 'severe or repeated' indicate that one single severe act may constitute bullying despite the absence of recurrence.

Besides, Anti-Bullying Act of 2013 also sets out several duties imposed on the schools to adopt policies to address the existence of bullying in their respective institutions. Then the Act also explains about the process of reporting of bullying.

Hence, it is proposed for Malaysia to examine the Anti-Bullying Act of 2013 especially with regard to the definition of bullying. Although, it appears that the definition of bullying does not comply with the standard definition given by the scholars, namely Olweus, but such definition is still regarded as wide-ranging because the definition was designed to be flexible to cater the definition of bullying. The flexibility can be shown whereby bullying is not only limited to acts but also extended to words. Then, the effect of bullying is not only confined to physical but also to emotional harm. Moreover, the requirement of repetition is not mandatory but depending on the intensity of the bullying act itself and importantly bullying includes cyberbullying.

\section{Conclusions}

Bullying is not a trivial matter and if not handled properly, it could lead to health problems [29]. It is believed that bullying can be tackled through legal approach. Despite the absence of specific law on bullying, action can be still taken against bullies under the Penal Code. This is because based on the above definitions, bullying consists of a number of elements that may fall under offending provisions of the Penal Code. However, using the Penal Code alone to address the issue of bullying may not be sufficient. There are certain bullying acts such as school pranks and teasing that may fall outside the scope of the Penal Code and thus leave no action to be taken. Therefore, in order to provide extensive protection for bullying victims, a specific law on bullying is needed to be in place. To begin with, reference can be made to the Anti-Bullying Act of 2013, which sets out the definition of bullying and its legal framework. This is consistent with Article 19 of the CRC, which clearly states that the State Parties (including Malaysia) should take all measures including legislative approach to protect the child from all forms of physical or mental violence, injury or abuse.

\section{Acknowledgements}

This research is a part of the output under grants i.e. DCP-2017-009/5 and FRGS/2/2014/SSI10/UKM/03/1.

\section{REFERENCES}

[1] P.K. Smith. Bullying in Life-Span Perspective: What Can Studies of School Bullying, Journal of Community \& Applied Social Psychology, Vol. 7, 249-255, 1997.

[2] P.K. Smith. School-based interventions to address bullying. Eesti Haridusteaduste Ajakiri. Estonian Journal of Education, Vol.4, No.2, 142-164, 2016.

[3] D. Olweus. Aggression in schools: Bullies and whipping boys, Washington, Hemisphere, 1978.

[4] E. Menesini, \& C. Salmivalli. Bullying in schools: the state of knowledge and effective interventions. Psychology, health \& medicine, Vol.22, No.1, 240-253, 2017.

[5] M. Iossi Silva, B. Pereira, D. Mendonça, B. Nunes, \& W. Oliveira. The involvement of girls and boys with bullying: an analysis of gender differences, International journal of environmental research and public health, Vol.10, No.12, 6820-6831, 2013

[6] B. Sivaraman, E. Nye, \& L. Bowes. School-based anti-bullying interventions for adolescents in low-and middle-income countries: A systematic review, Aggression and Violent Behavior, Vol.45, 154-162, 2019.

[7] D.N. Türkmen, M.H. Dokgöz, S.S. Akgöz, B.N. Eren, H.P. Vural \& H.O. Polat, Bullying among High School Students, Maedica, Vol. 8 No.2, 143-152, 2013.

[8] Audrey Vijaindren. (2017). Bullying: Can we end it? New Straits Time. Retrieved from https://www.nst.com.my/new s/exclusive/2017/06/249980/bullying-can-we-end-it [Accessed June 2019].

[9] E. Erginoz, M. Alikasifoglu, O. Ercan, O. Uysal, Z. Alp, S. Ocak, G. Oktay Tanyildiz, B. Ekici, I.K. Yucel, \& D. Albayrak Kaymak, The role of parental, school, and peer factors in adolescent bullying involvement: Results from the Turkish HBSC 2005/2006 study, Asia Pacific Journal of Public Health, Vol. 27, No.2, 1591-1603, 2015.

[10] D. Wolke, \& S.T. Lereya, (2015). Long-term effects of bullying. Archives of disease in childhood, Vol.100, No.9, 879-885, 2015.

[11] D. Olweus. A useful evaluation design and effects of the Olweus Bullying Prevention Program, Psychology, Crime \& Law, Vol.11, 389-402, 2005.

[12] K. Rigby. School perspectives on bullying and preventative strategies: An exploratory study, Australian Journal of Education, Vol. 61, No.1, 24-39, 2017.

[13] P.K. Smith, D. Pepler, \& K. Rigby. Bullying in schools: How successful can interventions be? New York, NY, Cambridge University Press, 2004.

[14] Bernama. (2017). Students' deaths cast spotlight on bullying. https://www.malaymail.com/news/malaysia/2017/12/24/st udents-deaths-cast-spotlight-on-bullying/1539359

[Accessed June 2019].

[15] H.K. Al-Raqqad, E.S. Al-Bourini, F.M. Al Talahin, \& R.M.E. Aranki. The Impact of School Bullying on Students' 
Academic Achievement from Teachers Point of View. International Education Studies, Vol.10, No.6, 44-50, 2017.

[16] D.L. Espelage, M.J. Van Ryzin \& M.K. Holt. Trajectories of bully perpetration across early adolescence: Static risk factors, dynamic covariates, and longitudinal outcomes, Psychology of violence, Vol. 8, No.2, 141, 2018.

[17] J. Dillon. No Place for Bullying: Leadership for Schools That Care for Every Student, California, Corwin, 2012.

[18] M.C. Aalsma \& J.R.Brown, What Is Bullying? Journal of Adolescent Health, Vol.43, No.2, 101-102, 2008.

[19] E. Menesini, \& C. Salmivalli. Bullying in schools: the state of knowledge and effective interventions. Psychology, health \& medicine, Vol.22, 240-253, 2017

[20] A.A.Volk, A.V. Dane, \& Z.A. Marini. What is bullying? A theoretical redefinition. Developmental Review, Vol.34, Vol.4, 327-343, 2014.

[21] A.A.Volk, R. Veenstra, \& D.L. Espelage. So you want to study bullying? Recommendations to enhance the validity, transparency, and compatibility of bullying research. Aggression and violent behavior, Vol.36, 34-43, 2017.

[22] W.S. WI, S.M. Tan, T. Iryani, S. Syamsul, A. Aniza, \& S. Zasmani. School bullying amongst standard six students attending primary national schools in the federal territory of Kuala Lumpur: The prevalence and associated socio demographic factors. Malaysian Journal of Psychiatry, Vol.18, No.1, 2009.

[23] Azizi Hj Yahaya, \& Abdul Latif Ahmad. Persepsi guru dan pelajar terhadap perlakuan buli di kalangan pelajar sekolah menengah daerah Batu Pahat. Jurnal Teknologi, Vol.43, 63-86, 2005.

[24] Surat Pekeliling Ikhtisas Bil 8 Tahun 2010, Garis Panduan Mencegah dan Menangani Perbuatan Buli Dalam Kalangan Murid di Sekolah, dated 29 July 2010 by Ministry of education, Malaysia. [Accessed June 2019].

[25] P.K. Smith. School Bullying. Sociologia, Problemas e Práticas, Vol.71, 2013.

[26] H. Vandebosch, \& K. Van Cleemput. Defining cyberbullying: A qualitative research into the perceptions of youngsters. CyberPsychology \& Behavior, Vol.11, No.4, 499-503, 2008.

[27] Anita Abdul Rahim, Tengku Noor Azira Tengku Zainudin, Ramalinggam Rajamanickam. The involvement of school students in criminal activities and its position in the Malaysian Law. Mediterranean Journal of Social Sciences, Vol.6, No.4, 403, 2015.

[28] Anita Abdul Rahim, Tengku Noor Azira Tengku Zainudin, Ramalinggam Rajamanickam, Mohamad Afiq Taqiudin Roslan. School Students Committing Crime: The Position under the Malaysian Criminal Law, Full Paper Proceeding ITMAR -2014, Vol. 1, 542-549, 2014.

[29] Ramalinggam Rajamanickam, Tengku Noor Azira Tengku Zainudin, Zainunnisa Abdul Rahman \& Ahmad Azam Mohd. Shariff. Prohibiting "Ragging" in the Malaysian Educational Institutions: Is the Law Adequate? The Social Sciences, Vol.12, No.8, 1440-1443, 2017. 